\title{
THE ATHENIAN SOCIETY OF QUEEN'S COLLEGE
}

\author{
By Mildred R. Woodward
}

Cut off from easy access to the outside world, the boys of the eigbteenth-century American college bad to find whatever intellectual stimulation they could in their own circle of friends. The old minute book of The Athenian Society reveals to such an inquiring student as Miss Woodward, a junior at the New Fersey College for Women, a stirring picture of the intellectual life which the students of Queen's College made for themselves during the Revolution and for a few years thereafter. It contains, furtbermore, what we believe to be the earliest reference to a library at Rutgers, the modest beginning from wbich the present University Library may bave grown.

Hanks to a friend of the University, the story of Rutger's oldest literary society-probably its first under-

1 graduate organization - has at last been disclosed. We have known that in the early years of Queen's College there was a group called the Athenian Society; it was mentioned briefly in The Fohn Bogart Letters. ${ }^{1}$ But when the Society was begun, who were its members, what were its activities, how long it continued - all this, until three years ago, remained a mystery. Then came the gift of the Reverend Dr. George B. Kinkead of Washington, D. C., who presented to the University the old minute book of the Athenian Society, covering almost, if not quite, the full period of its existence.

This volume, browned with age but well preserved, bears the title Transactions of the Athenian Society from the year 1776 to 1786 . Its pages, nearly 200 in number, are alive with notes of unusual historic interest. In addition to the list of 54 members, whose signatures are appended to the declaration of purpose, the "laws and regulations" of the Society, together with the "orders" adopted and the accounts of the various meetings, throw a new light upon early student life at Old Queen's.

We have not the complete story of all that happened to the book through the I 50 years following the Society's close. It appears to have passed through the hands of Colonel John Taylor, tutor of Queen's, who headed the membership list, and the Reverend Henry Kollock, a graduate of Princeton, who

\footnotetext{
${ }^{1}$ The Fobn Bogart Letters, New Brunswick, N. J., Rutgers University, IgI4.
} 
was a son of Shepard Kollock, the famous New Jersey printer. Above Kollock's signature on the title page is this inscription: "This Book was presented to me this day by Colonel John Taylor, for whom I entertain the utmost esteem. Oct. 24, I792." Years later it came into the possession of a person related by marriage to the family of William Crooke, a member of the Society, who gave it to Dr. Kinkead. Dr. Kinkead appreciated the interest the volume would have for Rutgers and returned it to the place of its origin.

The precise date of the founding of the Society is not given. The minutes cover the period from May 28, 1776, to October 4, I 786, but from an entry of "orders" adopted on November 24, I773, we conclude that it existed at least three years earlier than the minutes indicate. It follows, therefore, that the Society must have begun within the first two years after the opening of the College in November, 1771. Among the members was Matthew Leydt, the first graduate of Queen's, sole member of the class of I774. The Athenian Society, therefore, antedated by at least three years the Phi Beta Kappa Society, founded at William and Mary on December 5, 1776 .

At all of the nine colonial colleges, indeed, literary societies were getting under way during this period. Besides the Athenian Society, there was at Queen's the Polemical Society as early as 1778 , but little more is known of it than the name. At Princeton, New Jersey's other colonial college, Aaron Burr had been prominent in establishing the Whig Club in 1769 , and a year later James Madison had been one of the founders of the Cliosophic Society. A Speaking Club was organized at Harvard in 1770 , while Columbia, then King's College, had a debating society as early as 1766 , and Yale had one in 1768 . Brown, Pennsylvania, and Dartmouth also had their literary clubs.

It may reasonably be inferred that the founders of the Society patterned its aims and ideals after those of the College. The royal charter, granted in 1766 and amended in 1770 , established Queen's College "for the education of youth in the learned languages, liberal and useful arts and sciences, and especially in divinity, preparing them for the ministry and other good offices." In similar vein the purpose of the Athenian Society was set forth as follows:

${ }^{2}$ Demarest, William H. S., A History of Rutgers College, New Brunswick, 1924, p. 75. 
The Arts and Sciences have ever been admired in all the polite Nations and Ages of the World. By these the Minds of Men have been adorned with a variety of useful and curious Knowledge. It is Learning which irradiates the Soul and dispels those Clouds of Ignorance which continually surround the Minds of the Illiterate. From these Considerations we the Subscribers are induced to form ourselves into a Society (which shall go by the Name of THE ATHENIAN SOCIETY.) in order to polish our Minds, and beautify our Manners. We also fully agree to be directed and governed by such Laws as shall be hereafter specified of which our Names affixed to this Instrument of Subscription shall be a sufficient Testimony. ${ }^{3}$

The years of the Athenian Society's existence must have been busy ones indeed. Meetings were held every Wednesday evening in a college room. Each member who did not attend a meeting was fined a sum not exceeding six pence, while those who were late had to pay two pence.

Let us sit in on one of the meetings of the Society as it is recorded for us by the secretary:

I78I, New Brunswick, Wednesday Evening, July I8th, the Athenian Society met and proceeded to business. Mr. Taylor President. Mr. Henry Vice President. Mr. Vice President opened the Society by speaking on Happiness, his own composition.

Composers. Mr. Best read on filial Piety.

Mr. Freligh read the Character of a Miser.

Mr. Henry Junr. read on Hypocrisy.

Mr. Bogart read on Witchcraft.

Mr. Best spoke from the United States Magazine.

Readers. Mr. Morris read from the Roman Antiquities.

Mr. Stewart read from Spectator.

Mr. Kirkpatrick read from Voltair.

Mr. Freligh spoke from the Art of Speaking.

Mr. Henry Junr. spoke from the Preceptor.

Mr. Morris spoke from Addisons Cato.

Mr. Kirkpatrick spoke from Thompsons Seasons.

Mr. Bogart spoke an Elogium on General Washington.

Mr. Stewart spoke from Voltair.

Messrs. Schureman, Van Harlingen, Cortlandt \& Crooke absent. Then the Society was dismissed.

How fine it would be if the secretary had recorded the minutes less topically and less tersely, and had given, for instance, a description of $\mathrm{Mr}$. Bogart's reading on witchcraft, or Mr.

${ }^{3}$ In all quotations from Transactions of the Atbenian Society, the spelling, punctuation, and capitalization appear here as in the original. The pages are not numbered. 
Henry's opinion of hypocrisy, for here men were being trained for the fields which lay before them, and we wonder just how the material presented at meetings helped them or affected their opinions. Here were young men destined to become leaders in public life-in law, in education, in the church. To John Bogart, a graduate of 1778 , "fell the honor of keeping Queen's College alive during the dark days of the Revolution," for after his graduation he became tutor at the College. Simeon De Witt, Bogart's close friend, was later to become a mathematician, philosopher, and geographer-general on Washington's staff. Another member, Jeremiah Smith, of the class of 1780 , was Congressman from I79I to I799, and subsequently governor of New Hampshire. The faculty, too, was represented in the Society. Jacob R. Hardenbergh, the president, General Frederick Frelinghuysen, tutor in the College, and Andrew Kirkpatrick, tutor in the Grammar School, and later Chief Justice of New Jersey, were all members. How much, we wonder, might the stimulating hours spent in the Society's rooms have inspired these men to future achievement, and otherwise shaped their careers?

The meetings followed the same general plan shown by the minutes of this one until debating became a part of the exercises of the Society in February, I 782. Thereafter the meeting was begun with a statement of a question by one of the members, following which two members spoke and the subject for disputation was argued. Then two other members talked, and several read from such authors as Swift, Æsop, Addison, Milton, Pope, Shakespeare, and Chesterfield. During the last part of each meeting the other members also spoke. At the time of the introduction of debating, it was ordered

that disputation be introduced and henceforth considered and appointed as one of the stated exercises of the Athenian Society, to be carried on and regulated in the manner following. viz. That at every stated meeting of the Society it shall be lawful for any member to propose a subject for disputation which if approved by the President, shall be entered on the minutes, and that the person so proposing shall have the privilege of choosing the side of the question.

In keeping with the spirit of the times, the discussions frequently touched upon issues of the war, for example, a speech on liberty, a letter to a Tory, a speech concerning the future

- Tbe Fobn Bogart Letters, p. 39. 
glories of America, and a reading on patriotism. Other related topics included an address to General Washington, a reading on the origin of war, and a speech on the horrors of war. Perhaps the disputations aroused more patriotic interest than the readings and speeches, for what student of that day would not have disputed over "Wether the Americans who have joined the British Army, should be permitted to return to this Country and enjoy its Liberties," or "Whether the Continuation of the War is to be preferred before a peace short of the absolute Independence of America."

Of a more peaceful character are the opinions of the place of social life in the mind and interest of the student which are reflected in readings, speeches, and debates. Topics included the reading of a letter to a young lady, a piece on marriage, a speech against matrimony, speeches on love, and the reading of an excerpt on dancing. Certainly such subjects as "Wether Dancing is a necessary Accomplishment to a Young Gentleman," "Wether the Company of the Ladies of virtuous Character is disadvantageous to a person in his Studies or not," and "Whether Love is an interested or a disinterested Passion" are all topics that are disputed and discussed by students of today, though their vocabularies are very different.

We too wish "to polish our Minds, and beautify our Manners," though we would not spend evenings discussing the art of speaking, generosity, sociableness, friendship, fidelity, the improvement of life, our duty to neighbors, and the modern manner of spending the Sabbath. We might very well give our attention, however, to "The Head-dress of the Ladies," listen with interest to an "Address to those who practice horse racing," and enter into discussions roused by such questions as these: "Is travelling advantageous to Person of a liberal Education?" "That Reputation is preferable to life," "That the Dictates of Conscience ought not to be followed in all Cases," and "Wether the Advantage arising from the Study of the dead Languages will compensate for the time spent in acquiring a knowledge of them."

The laws of the Society are indeed amusing when compared with those of present-day societies. For example, "No Person shall be admitted into this Society, who is of a known vicious character, and who might in any measure disgrace it by being 
a Member." Members were admitted by ballot, and each, upon his entrance, was required to pay ten shillings. At first, all members took their turns as president, but later this law was repealed, and the president also was elected by ballot.

Other laws prescribed conduct at meetings:

Every Member shall rise up when he speaks and always address the President. Nor shall any two Persons speak at once, upon the penalty of two pence for each offence. Everyone shall be allowed to make his Remarks upon the performance of each Member provided it is with Candour, and if any Person shall be deemed ungenerous in his Observations by a majority of the Members he shall be punished in a fine not exceeding two Shillings. . . . No Member shall make his Remarks untill asked by the President unless it is with his permission, on penalty of three pence. . . . No private Conversation or even Whispering shall be allowed in the Society, unless leave be obtained from the President. . . . No Member shall leave his Seat without permission from the President, on penalty of two pence. . . . No Person shall speak above four times upon any particular Debate raised in the Society, without leave from the President on penalty of two pence.

On various occasions throughout the life of the Society, orders were passed which modified the laws or made new ones. These cast additional light upon the Society's activities. Among the new laws are those which stated

that the Society be opened by an Oration either from the President or some one of its Members, that nearly one half of the Members read from some aproved Author, while the others read peices of their own composition, that each person speak every evening, that four members speak immediately after the Composers have read their peices, that no spirituous liquors be drank during the setting of the Society.

Not the least of the Society's achievements was the founding of a library. The laws and regulations provided for the appointment of a librarian who should "attend at the Library every Monday from one to two o'clock in the Afternoon." It was his duty to "keep an exact account of all Monies belonging to the Library, as also of all Books when taken out and when returned." A person "guilty of a breach of any regulation of the Library" was fined two shillings. The librarian, too, had to pay a penalty if any book was lost or damaged through his carelessness or neglect. To support the library each member was assessed a fee of one dollar yearly. 


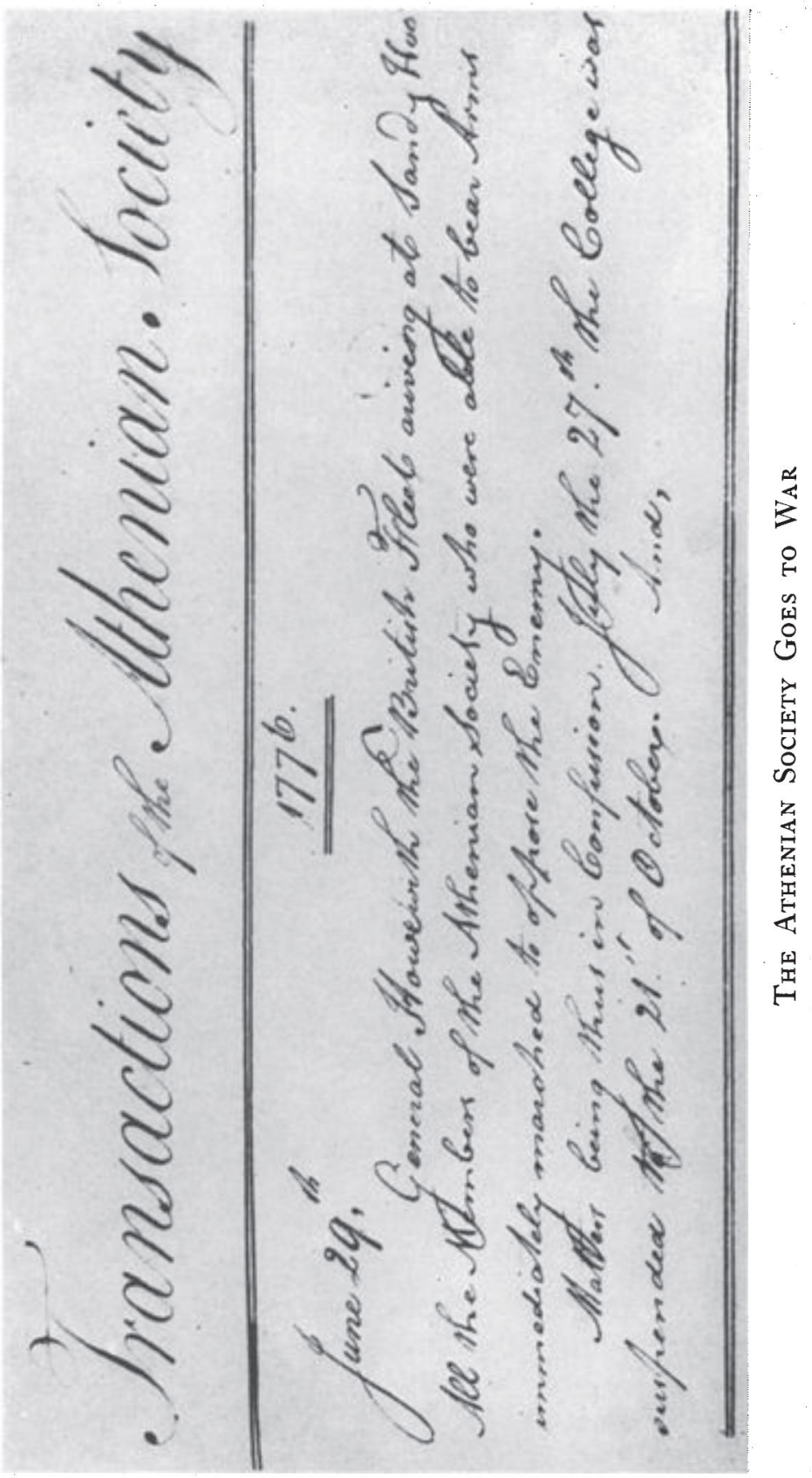


In the midst of these peaceful proceedings we are suddenly presented with a picture of college students leaving their classrooms to take up arms against the British. In the minutes of June 29, 1776 , only a few days before independence was declared, the secretary wrote the following:

General Howe with the British Fleet ariving at Sandy Hook All the Members of the Athenian Society who were able to bear Arms immediately marched to oppose the Enemy. Matters being thus in Confusion July the 27 th, the College was suspended to the 21st. of October.

Late in that year it was recorded that

The British Army under the command of General Howe having invaded the State of New Jersey, and penetrating as far as the City of New Brunswick on the first day of December in the year 1776 . The Members of the Athenian Society still inspired by Patriotism, and zealous to promote the interests of America, leaving their peaceable abodes, again assisted their Countrymen to repel an Enemy endeavouring to establish a System of Tyranny and Oppression.

Meetings were not held again until the spring of 1778 , when by an order of the faculty the College was moved to North Branch. At that time a number of the former members assembled and resumed business.

On two other occasions the Society was forced to suspend meetings, once when General Clinton's march through the state in June, 1778, was halted at the Battle of Monmouth, and again on January $3,178 \mathrm{I}$, when the Society was meeting in the town of Hillsborough, "in consequence of a mutiny in the Pennsylvania Line and their marching through this place."

Apparently the Society never fully recovered from the distractions of war. According to the record, no meetings were held from I783 until October I, I786, when "the Society met after an Interval of almost three Years and took into consideration, the means of reviving the Institution." Only one meeting was held after this. On October 4 the secretary made the final entry which marked the passing of the Athenian Society:

ALAS! These Resolutions are like the Morning Cloud._-

ATHENIANS! ATHENIANS you are no more.-

From your ashes has arisen the Federal Society, and may it long exist and be a mean[s] of Instruction to many. 